\title{
Upaya Meningkatkan Pembelajaran Pada Masa Pandemi Covid-19 Dengan Belajar Dari Rumah/Belajar Jarak Jauh di SMP Negeri 3 Singkawang
}

\author{
Risma Purnama \\ SMP N 3 Singkawang, Singkawang, Indonesia \\ rismapurnama71@gmail.com
}

KataKunci :

Meningkatkan,

Pembelajaran, Masa

Pandemi

\begin{abstract}
ABSTRAK
Tujuan penelitian ini adalah 1. Memberikan gambarantentang melaksanakan pembelajaran pada masa pandemi covid-19 dengan belajar dari rumah/belajar jarak jauh di SMP Negeri 3 Singkawang. 2. Memberikan gambarantentang melaksanakan peningkatan pembelajaran pada masa pandemi covid-19 dengan belajar dari rumah/belajar jarak jauh di SMP Negeri 3 Singkawang.Upaya meningkatkan pembelajaran pada masa pandemi covid-19 dengan belajar dari rumah/belajar jarak jauh di SMP Negeri 3 Singkawang Tahun 2020, penulis sebagai Kepala SMP Negeri 3 Singkawang melakukan monitoring kegiatan guru dalam pelaksanaan pembelajaran jarak jauh.Pembelajaran pada masa pandemi Covid-19 dengan belajar dari rumah/belajar jarak jauh dengan menggunakan media interaksi yang disiapkan oleh manajemen sekolah.Manajemen SMP Negeri 3 Singkawang memanfaatkan media interaksi yang murah dan mudah digunakan oleh guru dan siswa.Pada masa pandemi Covid-19 ini menjadikan semua guru SMP Negeri 3 Singkawang terampil menggunakan media TIK dan mampu membuat video pembelajaran yang diunggah di youtube SMP Negeri 3 Singkawang.Pelayanan belajar dari rumah/belajar jarak jauh kepada siswa berjalan lancar.
\end{abstract}

\section{PENDAHULUAN}

CoronaVirus-19 (COVID) telah dinyatakan sebagai pandemi dunia oleh WHO. Coronavirus adalah zoonosis atau virus yang ditularkan antara hewan dan manusia. Per tanggal 21 Maret 2020, jumlah kasus penyakit ini mencapai angka 279,469 jiwa yang tersebar di 166 negara termasuk Indonesia. Sehingga Presiden Indonesia telah menyatakan status penyakit ini menjadi tahap Tanggap Darurat pada tanggal 17 Maret 2020 yang berimbas pada penutupan kegiatan belajar mengajar di sekolah.

Penutupan kegiatan belajar mengajar di sekolah berdampak terhadap guru, peserta didik dan orang tua. Dalam kondisi yang tidak biasa ini teknologi dapat membantu proses belajar dari jarak jauh menjadi lebih mudah untuk diterapkan.

Guru mengajar dari rumah/sekolah ketika peserta didik berada di rumah adalah solusi untuk mengatasi pandemi covid-19 agar dapat memutus mata rantai penyebarannya. SMP Negeri 3 Singkawang memberikan solusi pada masa ini dengan kegiatan belajar mengajar jarak jauh yang memungkinkan pengajaran dan pembelajaran dilakukan di mana saja, kapan saja, dengan perangkat apa saja. Sehingga pendidikan dapat terus berjalan, terlepas situasi yang tengah kita hadapi. 
Sebagai tenaga pendidik, tugas utama guru adalah memberikan ilmu yang bermanfaat bagi masa depan anak. Hal tersebut senada dengan pendapat Darmadi (2015:162) yang menyatakan bahwa peran guru tidak akan bisa tergantikan oleh elemen apapun walaupun dengan mesin canggih sekalipun. Di samping itu, seorang guru juga diharapkan mampu memberikan pendidikan moral dan sopan santun kepada anak, menanyakan ketika anak mengalami kesulitan dalam proses belajar mengajar, memberi motivasi belajar, memberi arah kegiatan belajar, memberi fasilitas untuk proses belajar anak, dan sebagai penengah terrhadap kesulitan belajar maupun bergaul yang mungkin dihadapi anak di sekolah.

Guru adalah semua orang yang mempunyai wewenang serta mempunyai tanggung jawab untuk membimbing serta membina murid (Hamid, 2017). Menurut UU No. 14 Tahun 2005 Tentang Guru dan Dosen, pengertian guru adalah tenaga pendidik profesional yang memiliki tugas utama untuk mendidik, mengajar, membimbing, mengarahkan, melatih, menilai dan mengevaluasi peserta didik pada pendidikan anak usia dini melalui jalur formal pendidikan dasar dan pendidikan menengah.

Sejalan dengan tantangan kehidupan global pada masa Pandemi COVID-19 ini, peran dan tanggung jawab guru pada masa mendatang akan semakin kompleks, sehingga menuntut guru untuk senantiasa melakukan berbagai peningkatan dan penyesuaian kemampuan profesionalnya. Guru harus lebih dinamis dan kreatif dalam mengembangkan proses pembelajaran peserta didik. Guru di masa mendatang tidak lagi menjadi satu-satunya orang yang paling well informed terhadap berbagai informasi dan pengetahuan yang sedang tumbuh, berkembang, berinteraksi dengan manusia di jagat raya ini. Di masa depan, guru bukan satu-satunya orang yang lebih pandai di tengah-tengah peserta didiknya.

Peraturan Menteri Negara Pendayagunaan Aparatur Negara dan Refomasi Birokrasi No. 16 Tahun 2009, Bab VII Pasal 13 ayat 2 menjelaskan rincian kegiatan guru matapelajaran sebagai berikut

1. Menyusun kurikulum pembelajaran pada satuan pendidikan,

2. Menyusun silabus pembelajaran,

3. Menyusun rencana pelaksanaan pembelajaran,

4. Melaksanakan kegiatan pembelajaran,

5. Menyusun alat ukur/soal sesuai mata pelajaran,

6. Menilai dan mengevaluasi proses dan hasil belajar pada mata pelajaran yang diampunya,

7. Menganalisis hasil penilaian pembelajaran,

8. Melaksanakan pembelajaran/perbaikan dan pengayaan dengan memanfaatkan hasil penilaian dan evaluasi,

9. Menjadi pengawas penilaian dan evaluasi terhadap proses dan hasil belajar tingkat sekolah dan nasional,

10.Membimbing guru pemula dalam program induksi,

11.Membimbing siswa dalam kegiatan ekstrakurikuler proses pembelajaran

12.Melaksanakan pengembangan diri,

13.Melaksanakan publikasi ilmiah,

14.Membuat karya inovatif.

Pada poin 4 rincian tugas guru mata pelajaran di atas yaitu melaksanakan kegiatan pembelajaran. Jadi gurumelaksanakan pembelajaran bagi peserta didik yang belajar dari rumah/belajar jarak jauh. Upaya meningkatkan pembelajaran pada masa pandemi covid-19 dengan belajar dari rumah/belajar jarak jauh di SMP Negeri 3 Singkawang Tahun 2020, penulis sebagai Kepala SMP Negeri 3 Singkawang melakukan monitoring kegiatan guru dalam pelaksanaan pembelajaran jarak jauh.Dalam kehidupan sehari-hari tidak terlepas dari kegiatan belajar, baik ketika sendiri maupun berkelompok. Tidak ada batas ruang, waktu dan usia untuk melakukan kegiatan belajar, karena perubahan yang menuntut terjadinya aktivitas belajar tidak pernah berhenti.

Belajar dimaknai sebagai proses perubahan perilaku sebagai hasil interaksi individu dengan lingkungannya. Perubahan perilaku terhadap hasil belajar bersifat continiu, fungsional, positif, aktif, dan terarah (Pane, 2017:334). Belajar merupakan proses internal yang kompleks. Yang terlibat dalam proses internal tersebut adalah seluruh mental, yang meliputi ranah kognitif, afektif dan psikomotorik. 
Belajar adalah kegiatan berproses dan merupakan unsur yang sangat fundamental dalam penyelenggaraan jenis dan jenjang pendidikan, hal ini berarti keberhasilan pencapaian tujuan pendidikan sangat tergantung pada proses belajar peserta didik.

Belajar merupakan tahapan perubahan perilaku peserta didik yang relatif positif dan mantap sebagai hasil interaksi dengan lingkungan yang melibatkan proses kognitif (Syah, 2003 dalam Jihad, 2010). Belajar sebagai perubahan tingkah laku pada diri individu berkat adanya interaksi antara individu dengan individu dan individu dengan lingkungannya sehingga mereka mampu berinteraksi dengan lingkungannya (Burton, dalam Aunurrahman, 2009). Belajar adalah suatu perubahan di dalam kepribadian yang menyatakan diri sebagai suatu pola baru dari reaksi berupa kecakapan, sikap, kebiasaan, kepribadian atau suatu pengertian ( Educational Psychology, H.C. Witherington dalam Aunurrahman, 2009). Sedangkan Mohamad Surya (2004) mengungkapkan bahwa pembelajaran merupakan suatu proses perubahan yaitu perubahan perilaku sebagai hasil interaksi antara dirinya dan lingkungannya dalam memenuhi kebutuhan hidupnya.

Jadi dapat disimpulkan bahwa belajar menunjukkan suatu aktivitas pada diri seseorang yang disadari atau disengaja yang merupakan interaksi individu dengan lingkungannya sehingga hasil belajar ditandai dengan perubahan tingkah laku dalam kemampuan berpikir, pengetahuan, kecakapan, keterampilan, dan sikap.

Fase-fase belajar yang dikemukakan oleh Witting dalam Jihad, 2010 yaitu:

a. Tahap acquisition, yaitu tahapan perolehan informasi;

b. Tahap storage, yaitu tahapan penyimpanan informasi;

c. Tahap retrieval, yaitu tahapan pendekatan kembali informasi

Ciri-ciri belajar Hamalik, 2003 dalam Jihad, 2010 yaitu:

a. proses belajar harus mengalami, berbuat, mereaksi dan melampaui;

b. melalui bermacam-macam pengalaman dan mata pelajaran yang berpusat pada suatu tujuan tertentu;

c. bermakna bagi kehidupan tertentu;

d. bersumber dari kebutuhan dan tujuan yang mendorong motivasi secara keseimbangan;

e. dipengaruhi pembawaan dan lingkungan;

f. dipengaruhi oleh perbedaan-perbedaan individual;

g. berlangsung secara efektif apabila pengalaman-pengalaman dan hasil-hasil yang diinginkan sesuai dengan kematangan Anda sebagai peserta didik;

h. proses belajar terbaik adalah apabila Anda mengetahui status dan kemajuannya;

i. kesatuan fungsional dari berbagai prosedur;

j. hasil-hasil belajar secara fungsional bertalian satu sama lain tetapi dapat didiskusikan secara terpisah;

k. di bawah bimbingan yang merangsang dan bimbingan tanpa tekanan dan paksaan;

1. hasil-hasil belajar adalah pola-pola perbuatan, nilai-nilai, pengertian-pengertian, sikap-sikap, apresiasi abilitas dan keterampilan;

m. dilengkapi dengan jalan serangkaian pengalaman yang dapat dipersamakan dan dengan pertimbangan yang baik;

n. lambat laun dipersatukan menjadi kepribadian dengan kecepatan berbeda-beda;

o. bersifat kompleks dan dapat berubah-ubah, jadi tidak sederhana dan statis.

Sistem pembelajaran jarak jauh atau belajar dari rumah tidak mengurangi produktivitas, karena kunci efektifitas sistem pembelajaran jarak jauh adalah bagaimana seorang guru tetap kreatif untuk menyajikan pembelajaran jarak jauh dengan cara menyenangkan dan mudah dimengerti sehingga para siswa tidak merasa bosan dan tetap produktif di rumah.Program pembelajaran jarak jauh diharapkan dapat memberi pengalaman belajar yang bermakna bagi siswa tanpa terbebani tunt utan menuntaskan kurikulum untuk kenaikan kelas maupun kelulusan.Empat kunci pembelajaran jarak jauh ini dapat menjadi pembelajaran bermakna dan menyenangkan untuk peserta didik

a. Kemampuan guru memanfaatkan teknologi

Guru menunjukkan kemampuan dalam memanfaatkan media teknologi dengan presentasi Zoom, penugasan via Google Classroom, pre-test atau post-test dengan Quizizz, dan pemberian tugas 
Journal of Educational Reviewand Research

Vol.4 No.1,July 2021.Page:73 -84

e-ISSN: 2597-9760,p-ISSN: 2597-9752

proyek dengan pemanfaatan Google Drive, presentasi interaktif dengn Peardeck, dan lain-lain. Hal ini mutlak harus dilakukan untuk mentranfer knowledge kepada peserta didik secara menarik dan efektif.

b. Pembelajaran terencana dan efektif

Guru menyajikan pembelajaran terencana dan efektif dalam keterbatasan waktu. Hal ini bisa dilakukan dengan mempersiapkan quality lesson plan dan mengatur langkah-langkah pembelajaran yang detail.Guru dan peserta didik dapat menetapkan tujuan pembelajaran sesuai ketersediaan waktu dan memilih materi yang akan disampaikan dengan langkah-langkah tepat dan akurat. Di sini guru dituntut pula untuk mengatur waktu dengan baik.

c. Menyatukan persepsi dan konsentrasi peserta didik

Bagaimana guru mampu menyatukan persepsi dan konsentrasi peserta didik serba berjauhan. Ini hanya bisa dilakukan oleh guru yang memiliki visi jelas dalam pembelajaran dan mampu menjalin ikatan batin dengan peserta didik dengan melakukan perannya sebagai motivator, fasilitator, mediator, dan komunikator.

d. Penguatan karakter peserta didik

Guru menyampaikan pesan kepada peserta didik agar menjadi anak yang tangguh, mengingat dalam kondisi masyarakat yang sedang diuji secara fisik dan mental akibat penyebaran Covid-19 yang berdampak kepada pembelajaran peserta didik menjadi serba terbatas dalam berkomunikasi, berinteraksi, dan berkreasi. Susanto dalam Kompas.com 2020 (Selasa, 14 April 2020)

Dalam Permendikbud No. 22 tahun 2016 dinyatakan bahwa proses pembelajaran pada satuan pendidikan diselenggarakan secara interaktif, inspiratif, menyenangkan, menantang, memotivasi peserta didik untuk berpartisipasi aktif, serta memberikan ruang yang cukup bagi prakarsa, kreativitas, dan kemandirian sesuai dengan bakat, minat, dan perkembangan fisik serta psikologis peserta didik. Pelaksanaan pembelajaran adalah proses yang disusun dengan langkah-langkah tertentu agar mencapai hasil yang diharapkan.Pelaksanaan pembelajaran adalah suatu kegiatan belajar dengan interaksi yang terjadi antara guru dan siswa. Perencanaan pembelajaran yang disusun dengan menekankan pada beragam aktivitas yang menuntut siswa untuk lebih banyak terlibat aktif akan memberikan pengaruh terhadap pengalaman belajarnya (Anggraeni \& Akbar, 2018:6). Pelaksanaan pembelajaran yang dilakukan diarahkan untuk mencapai tujuan tertentu yang telah dirumuskan dalam rencanapelaksanaan pembelajaran. Pelaksanaan pembelajaran merupakan implementasi dari RPP, meliputi kegiatan pendahuluan, inti dan penutup.

1. Kegiatan Pendahuluan Dalam kegiatan pendahuluan, guru wajib:

a) menyiapkan peserta didik secara psikis dan fisik untuk mengikuti proses pembelajaran; b) memberi motivasi belajar peserta didik secara kontekstual sesuai manfaat dan aplikasi materi ajar dalam kehidupan sehari-hari, dengan memberikan contoh dan perbandingan lokal, nasional dan internasional, serta disesuaikan dengan karakteristik dan jenjang peserta didik; c) mengajukan pertanyaan-pertanyaan yang mengaitkan pengetahuan sebelumnya dengan materi yang akan dipelajari; d) menjelaskan tujuan pembelajaran atau kompetensi dasar yang akan dicapai; dan e) menyampaikan cakupan materi dan penjelasan uraian kegiatan sesuai silabus.

2. Kegiatan Inti

Kegiatan inti menggunakan model pembelajaran, metode pembelajaran, media pembelajaran, dan sumber belajar yang disesuaikan dengan karakteristik peserta didik dan mata pelajaran. Pemilihan pendekatan tematik dan /atau tematik terpadu dan/atau saintifik dan/atau inkuiri dan penyingkapan (discovery) dan/atau pembelajaran yang menghasilkan karya berbasis pemecahan masalah (project based learning) disesuaikan dengan karakteristik kompetensi dan jenjang pendidikan.

a) Sikap

Sesuai dengan karakteristik sikap, maka salah satu alternatif yang dipilih adalah proses afeksi mulai dari menerima, menjalankan, menghargai, menghayati, hingga mengamalkan. Seluruh aktivitas pembelajaran berorientasi pada tahapan kompetensi yang mendorong peserta didik untuk melakuan aktivitas tersebut.

b) Pengetahuan

Pengetahuan dimiliki melalui aktivitas mengetahui, memahami, menerapkan, menganalisis, mengevaluasi, hingga mencipta. Karakteritik aktivititas belajar dalam domain pengetahuan ini 
memiliki perbedaan dan kesamaan dengan aktivitas belajar dalam domain keterampilan. Untuk memperkuat pendekatan saintifik, tematik terpadu, dan tematik sangat disarankan untuk menerapkan belajar berbasis penyingkapan/penelitian (discovery/inquiry learning). Untuk mendorong peserta didik menghasilkan karya kreatif dan kontekstual, baik individual maupun kelompok, disarankan yang menghasilkan karya berbasis pemecahan masalah (project based learning).

c) Keterampilan

Keterampilan diperoleh melalui kegiatan mengamati, menanya, mencoba, menalar, menyaji, dan mencipta. Seluruh isi materi (topik dan sub topik) mata pelajaran yang diturunkan dari keterampilan harus mendorong peserta didik untuk melakukan proses pengamatan hingga penciptaan. Untuk mewujudkan keterampilan tersebut perlu melakukan pembelajaran yang menerapkan modus belajar berbasis penyingkapan/penelitian (discovery/inquiry learning) dan pembelajaran yang menghasilkan karya berbasis pemecahan masalah (project based learning).

3. Kegiatan Penutup

Dalam kegiatan penutup, guru bersama peserta didik baik secara individual maupun kelompok melakukan refleksi untuk mengevaluasi: a) seluruh rangkaian aktivitas pembelajaran dan hasil-hasil yang diperoleh untuk selanjutnya secara bersama menemukan manfaat langsung maupun tidak langsung dari hasil pembelajaran yang telah berlangsung; b) memberikan umpan balik terhadap proses dan hasil pembelajaran; c) melakukan kegiatan tindak lanjut dalam bentuk pemberian tugas, baik tugas individual maupun kelompok; dan d) menginformasikan rencana kegiatan pembelajaran untuk pertemuan berikutnya.

Berdasarkan Surat Edaran Nomor 15 Tahun 2020 Tentang Pedoman Penyelenggaraan Belajar Dari Rumah Dalam Masa Darurat Penyebaran Corona Virus Disease (Covid-19) dijelaskan bahwa selama masa darurat COVID-19, kepala satuan pendidikan melakukan langkah-langkah pelaksanan Belajar Dari Rumahdiantaranya yaitu Menetapkan model pengelolaan satuan pendidikan selama Belajar Dari Rumah. Media dan Sumber Belajar Pembelajaran Jarak Jauh Daring Pembelajaran di rumah secara daring dapat menggunakan gawai (gadget) maupun laptop melalui beberapa portal dan aplikasi pembelajaran daring.

Jadi pembelajaranpada masa Pandemi Covid-19 dengan belajar dari rumah (belajar jarak jauh) di SMP Negeri 3 Singkawang sebagai berikut:

1. Manajemen sekolah membentuk WhatsApp Grup kelas yang di dalamnya ada semua siswa dalam satu kelas, semua guru mata pelajaran yang mengajar di kelas tersebut, walikelas, guru BK dan kepala sekolah.

2. Guru diarahkan untuk membuat video pembelajaran yang diunggah di youtube SMP Negeri 3 Singkawang.

3. Manajemen sekolah juga membentuk Google Class Room yang di dalamnya ada semua siswa dalam satu kelas, guru mata pelajaran dan kepala sekolah.

4. Guru menyusun rencana pelaksanaan pembelajaran belajar dari rumah/belajar jarak jauh.

5. Guru membuat media pembelajaran berupa video yang diunggah di youtube SMP Negeri 3 Singkawang.

6. Pembelajaran menggunakan WhatsApp Grup kelas sesuai dengan jadwal yang telah disusun,

7. Pada proses pembelajaran di WhatsApp Grup kelas, guru melakukan kegiatan pendahuluan/pembuka, kegiatan inti, dan kegiatan penutup.

8. Pada kegiatan inti guru mengirim link video pembelajaran yang telah diunggah di youtube SMP Negeri 3 Singkawang.

9. Setelah siswa menyimak video pembelajaran, dilanjutkan dengan pambahasan materi pelajaran dan Tanya jawab di dalam WhatsApp Grup kelas.

10.Guru memberi tugas kepada siswa yang hasilnya diunggah di dalam Google Class Room (GCR) mata pelajaran.

11.Guru menutup pembelajaran di dalam WhatsApp Grup kelas.

12.Guru mengoreksi, menanggapi, dan menilai hasil tugas siswa di dalam Google Class Room (GCR) mata pelajaran. 
Metode yang digunakan dalam penelitian ini adalah action research. (jelaskan langkah-langkah penelitiannya seperti: Data : data dalam Penelitian Tindakan Sekolah (PTS) ini adalah data yang diperoleh dari kegiatan pembelajaran pada masa Pandemi Covid-19 dengan belajar dari rumah/belajar jarak jauh di SMP Negeri 3 Singkawang. sumber data : Sumber data dalam Penelitian Tindakan Sekolah (PTS) inivideo youtube SMP Negeri 3 singkawang, WAG (WhatSapp Grup) kelas, GCR (Google Class Room, Quizizz, zoom. pengumpulan data : pengumpulan data dalam Penelitian Tindakan Sekolah (PTS) ini adalah menggunakan lembar observasi dan dokumentasi. Lembar observasi dan dokumentasi dipergunakan untuk mendapatkan data peningkatan pembelajaran pada masa Pandemi Covid-19 dengan belajar dari rumah/belajar jarak jauh di SMP Negeri 3 Singkawang. teknik pengumpulan data : pelaksanaan Penelitian Tindakan Sekolah (PTS) ini melalui dua tahapan siklus, kedua tahapan tersebut terdiri dari perencanaan, tindakan, pengamatan, dan refleksi. analisis data : data yang dikumpulkan dari observasi dan dokumnetasi pembelajaran pada masa Pandemi Covid-19 dengan belajar dari rumah/belajar jarak jauh di SMP Negeri 3 Singkawang.

\section{HASIL DAN PEMBAHASAN}

PenelitiandilakukandiSMKMuditaSingkawang,denganjumlahpopulasi207siswadanjumlahsampel60siswa. TujuanpenelitianiniadalahuntukmelihatkorelasiantarapolaasuhorangtuaJadi pembelajaranpada masa Pandemi Covid-19 dengan belajar dari rumah (belajar jarak jauh) di SMP Negeri 3 Singkawang sebagai berikut:

1. Manajemen sekolah membentuk WhatsApp Grup kelas yang di dalamnya ada semua siswa dalam satu kelas, semua guru mata pelajaran yang mengajar di kelas tersebut, walikelas, guru BK dan kepala sekolah.

2. Guru diarahkan untuk membuat video pembelajaran yang diunggah di youtube SMP Negeri 3 Singkawang.

3. Manajemen sekolah juga membentuk Google Class Room yang di dalamnya ada semua siswa dalam satu kelas, guru mata pelajaran dan kepala sekolah.

4. Guru menyusun rencana pelaksanaan pembelajaran belajar dari rumah/belajar jarak jauh.

5. Guru membuat media pembelajaran berupa video yang diunggah di youtube SMP Negeri 3 Singkawang.

6. Pembelajaran menggunakan WhatsApp Grup kelas sesuai dengan jadwal yang telah disusun,

7. Pada proses pembelajaran di WhatsApp Grup kelas, guru melakukan kegiatan pendahuluan/pembuka, kegiatan inti, dan kegiatan penutup.

8. Pada kegiatan inti guru mengirim link video pembelajaran yang telah diunggah di youtube SMP Negeri 3 Singkawang.

9. Setelah siswa menyimak video pembelajaran, dilanjutkan dengan pambahasan materi pelajaran dan Tanya jawab di dalam Whats App Grup kelas.

10.Guru memberi tugas kepada siswa yang hasilnya diunggah di dalam Google Class Room (GCR) mata pelajaran.

11.Guru menutup pembelajaran di dalam WhatsApp Grup kelas.

12.Guru mengoreksi, menanggapi, dan menilai hasil tugas siswa di dalam Google Class Room (GCR) mata pelajaran.

Berdasarkan data hasil pembinaan kepala sekolah kepadaguru SMP Negeri 3 Singkawang pada awal Pandemi Covid-19 yaitu bulan Maret 2020 yaitu Pandemi Covid-19 yaitu semua guru masing-masing menggunakan pola yang berbeda-beda sehingga kepala sekolah kesulitan mengawasi aktifitas kegiatan guru dalam proses belajar mengajar, maka SMP Negeri 3 Singkawang menyusun pembelajaranpada masa Pandemi Covid-19 dengan belajar dari rumah/belajar jarak jauh yang manajemennya langsung dibimbing oleh kepala sekolah sebagai upaya meningkatkan pembelajaranpada masa Pandemi Covid-19 dengan belajar dari rumah/belajar jarak jauh di SMP Negeri 3 Singkawang. 
SMP Negeri 3 Singkawang sebagai sekolah rujukan sejakTahun Pelajaran 2017, hingga Tahun Pelajaran 2019 ini mejadi sekolah rujukan secara mandiri. Pada masa Pandemi Covid-19 merancang pembelajaran dengan belajar dari rumah/belajar jarak jauh.Berikut ini data jumlah guru di SMP Negeri 3 Singkawang dalam pelaksanaan Belajar Dari Rumah (BDR)/ Belajar Jarak Jauh(BJJ) sebelum tindakan.

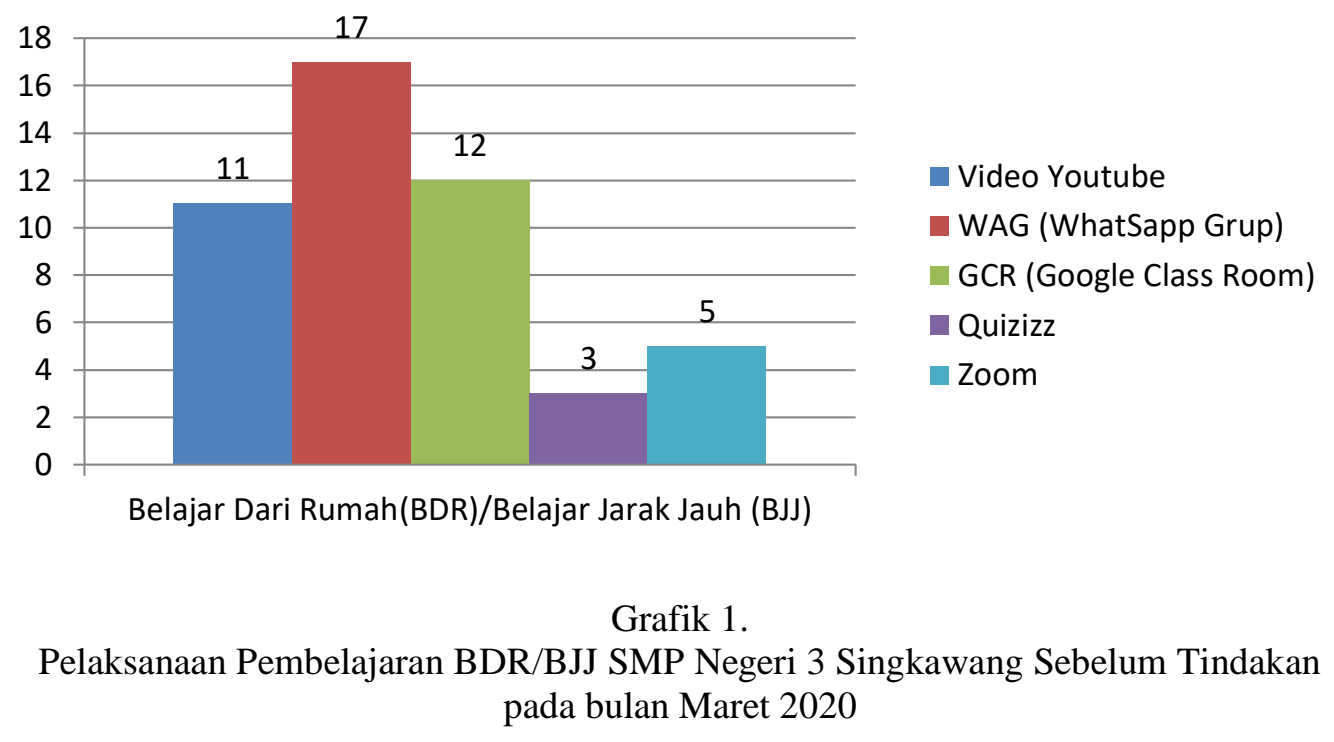

Pada bulan Maret 2020 belajar dari rumah/belajar jarak jauh yang dilaksanakan guru SMPN 3 Singkawang masih menggunakan media yang bervariasi sehingga belum terpantau secara intensif.Diantaranya ada yang menggunakan youtube, whatsapp, google class room, quiz, zoom, dll.Guru SMPNegeri 3 Singkawang berjumlah 32 orang. Guru yang menggunakan media youtube 11 orang yaitu 34,37\%. Guru yang menggunakan media WhatsApp Grup 17 orang yaitu 53,12\%. Guru yang menggunakan media Google Class Room 12 orang yaitu 37,50\%. Guru yang menggunakan media Quiziz 3 orang yaitu $9,75 \%$. Guru yang menggunakan media Zoom 5 orang yaitu $15,62 \%$. Jadi dari 32 orang guru SMP Negeri 3 Singkawang, pertama paling banyak menggunakan WhatsApp Grup.Selanjutnya yang kedua Google Class Room dan yang ketiga video youtube.

Kegiatan pelaksanaan belajar dari rumah/belajar jarak jauh merupakan kegiatan rutin proses belajar mengajar di SMP Negeri 3 Singkawang yang sudah terjadwal selama lima hari kerja. Manajemen sekolah membentuk WhatsApp Grup kelas yang di dalamnya ada semua siswa dalam satu kelas, semua guru mata pelajaran yang mengajar di kelas tersebut, walikelas, guru BK dan kepala sekolah. Guru diarahkan untuk membuat video pembelajaran yang diunggah di youtube SMP Negeri 3 Singkawang. Manajemen sekolah juga membentuk Google Class Room yang di dalamnya ada semua siswa dalam satu kelas, guru mata pelajaran dan kepala sekolah.

Pelaksanaaan belajar dari rumah/balajar jarak jauh menggunakan WhatsApp Grup kelas sesuai dengan jadwal yang telah disusun.Sesuai dengan jadwal, guru masuk WhatsApp Grup kelas melaksanakan pembelajaran dengan kegiatan pendahuluan/pembuka, kegiatan inti, dan kegiatan penutup. Pada kegiatan pendahuluan/pembuka, guru memberi salam, berdoa bersama, apersepsi dan lain-lain. Pada kegiatan inti, guru mengirimkan link video pembelajaran dari youtube SMP Negeri 3 Singkawang dan siswa menyimak video tersebut.Setelah menyimak video guru dan siswa berinteraksi seperti Tanya jawab, kuis, dan lainlain.Pada kegiatan penutup, guru dan siswa membuat kesimpulan tentang materi pelajaran.Kemudian guru memberi tugas siswa dan siswa mengunggah tugasnya ke dalam Google Class Room.Pengamatan dilakukan terhadapkegiatan belajar dari rumah/belajar jarak jauh pada bulan Juli2020.belajar dari rumah/belajar jarak jauh pada bulan Juli 2020 yaitu Video Youtube, WhatsApp Grup Kelas, Google Class Room, quizs, zoom. 


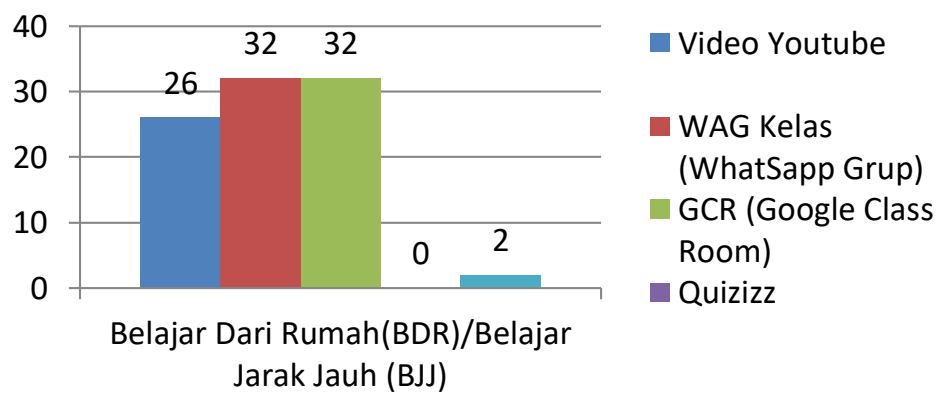

Grafik2.

Pelaksanaan Pembelajaran BDR/BJJ SMP Negeri 3 Singkawang Siklus 1 pada bulan Juli 2020

Dari grafik di atas dapat dilihat bahwa pada bulan Juli 2020 belajar dari rumah/belajar jarak jauh yang dilaksanakan guru SMPN 3 Singkawang sudah menggunakan media interksi yang efektif sehingga dapat terpantau secara intensif. Diantaranya ada yang menggunakan youtube, whatsapp grup kelas, google class room, quizizz, zoom, dll.Guru SMPNegeri 3 Singkawang yang berjumlah 32 orang menggunakan media youtube 26 orang yaitu $81,25 \%$. Guru yang menggunakan media WhatsApp Grup 32 orang yaitu $100 \%$. Guru yang menggunakan media Google Class Room 32 orang yaitu $100 \%$. Guru yang menggunakan media Quiziz 0 orang yaitu 0\%. Guru yang menggunakan media Zoom 2 orang yaitu $6,25 \%$.

Jadi pada siklus 1 semua guru sudah menggunakan WhatsApp Grup Kelas dan Google Class Room yang dibuat oleh manajemen sekolah.Masih ada 5 orang guru yang belum menggunakan video pembelajaran yang diunggah di youtube SMP Negeri 3 Singkawang. Hanya 2 orang guru yang mengunakan media zoom. Dan tidak ada lagi yang menggunakan media Quiziz karena semua sudah menggunakan Google Class Room.

Keberhasilan yang diperoleh selama siklus 1 ini adalah sebagai berikut:

1. Pada bulan Juli 2020sebagian besar guru atau $81,25 \%$ sudah membuat dan menggunakan video pembelajaran yang diunggah di youtube SMP Negeri 3 Singkawang dan dibagikan linknya ketika mengajar dalam WhatsApp Grup Kelas.

2. Pada bulan Juli 2020semua guru atau 100\% sudah menggunakan WhatsApp Grup Kelas dan Google Class Room dan terpantau aktifitasnya oleh manajemen sekolah.

3. Aktivitas gurudi sekolahmulaitumbuh mahir dalam penggunaan TIK.

4. Mata pelajaran yang tuntas semua pada kelas 7 yaitu Bahasa Inggris dan PJOK, kelas 9 yaitu PPKn.

5. $100 \%$ guru dan siswa melaksanakan belajar dari rumah/belajar jarak jauh menggunakan WhatsApp Grup Kelas dan Google Class Room yang disiapkan manajemen sekolah.

Pengamatan dilakukan terhadap kegiatan belajar dari rumah/belajar jarak jauh pada bulan Agustus 2020.Belajar dari rumah/belajar jarak jauh pada bulan Agustus2020 yaitu Video Youtube, WhatsApp Grup Kelas, Google Class Room, quiziz, zoom. 


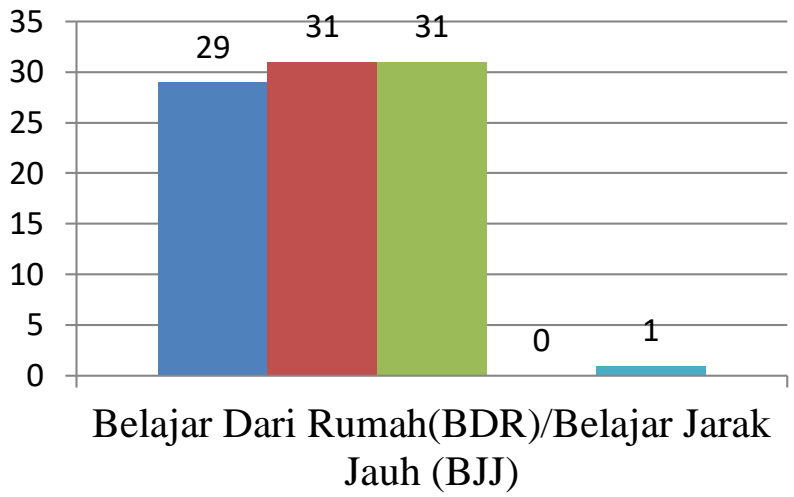

- Video Youtube

- WAG Kelas

(WhatSapp Grup)

GCR (Google Class

Room)

- Quizizz

Grafik 3. Pelaksanaan Pembelajaran BDR/BJJ SMP Negeri 3 Singkawang Siklus 2 pada bulan Agustus 2020

Dari grafik di atas dapat dilihat bahwa pada bulan Agustus 2020 belajar dari rumah/belajar jarak jauh yang dilaksanakan guru SMPN 3 Singkawang sudah menggunakan media interksi yang efektif sehingga dapat terpantau secara intensif. Diantaranya ada yang menggunakan youtube, whatsapp grup kelas, google class room, quizizz, zoom, dll.

Guru SMPNegeri 3 Singkawang menjadi 31 orang karena 1 orang guru meninggal dunia. Guru yang menggunakan media youtube 29 orang yaitu 93,54\%. Guru yang menggunakan media WhatsApp Grup 31 orang yaitu $100 \%$. Guru yang menggunakan media Google Class Room 31 orang yaitu $100 \%$. Guru yang menggunakan media Quizizz 0 orang yaitu $0 \%$. Guru yang menggunakan media Zoom 1 orang yaitu $3,23 \%$.

Jadi pada siklus 2 semua guru sudah menggunakan WhatsApp Grup Kelas dan Google Class Room yang dibuat oleh manajemen sekolah.Masih ada 2 orang guru yang belum menggunakan video pembelajaran yang diunggah di youtube SMP Negeri 3 Singkawang. Hanya 1 orang guru yang mengunakan media zoom. Dan tidak ada lagi yang menggunakan media Quizizz karena semua sudah menggunakan Google Class Room.

Keberhasilan yang diperoleh selama siklus 2 ini adalah sebagai berikut:

1. Pada bulan Agustus 2020sebagian besar guru atau 93,54\% sudah membuat dan menggunakan video pembelajaran yang diunggah di youtube SMP Negeri 3 Singkawang dan dibagikan linknya ketika mengajar dalam WatsApp Grup Kelas.

2. Pada bulan Agustus 2020semua guru atau 100\% sudah menggunakan WhatsApp Grup Kelas dan Google Class Room.

3. Semua guru SMP Negeri 3 Singkawang guru mahir dalam penggunaan TIK dan profesionalisme guru meningkat.

4. Mata pelajaran yang tuntas semua pada kelas 7 yaitu Bahasa Inggris, IPS dan Prakarya, kelas 9 yaitu PPKn.

5. $100 \%$ guru dan siswa melaksanakan belajar dari rumah/belajar jarak jauh menggunakan WhatsApp Grup Kelas dan Google Class Room yang disiapkan manajemen sekolah.

Pembelajaran pada masa pandemi covid-19 di SMP Negeri 3 Singkawangdengan belajar dari rumah/belajar jarak jauh dapat dilihat hasilnya pada siklus 1 dan siklus 2 sebagai berikut: 
DP

JOURNAL OF EDUCATIONAL
Journal of Educational Reviewand Research

Vol.4 No.1,July 2021.Page:73 -84

e-ISSN: 2597-9760,p-ISSN: 2597-9752

Tabel 3.

Hasil Belajar Dari Rumah/Belajar Jarak Jauh di SMP Negeri 3 Singkawang pada siklus 1 dan siklus 2

\begin{tabular}{cccccccc}
\hline & & \multicolumn{2}{c}{ Kelas } & \multicolumn{2}{c}{ Kelas 8} & \multicolumn{2}{c}{ Kelas 9 } \\
\cline { 3 - 8 } No & Siklus & $\begin{array}{c}\text { Jumlahpali } \\
\text { ng tinggi } \\
\text { tuntas }\end{array}$ & $\begin{array}{c}\text { Jumlah } \\
\text { paling } \\
\text { rendah } \\
\text { tuntas }\end{array}$ & $\begin{array}{c}\text { Jumlahpali } \\
\text { ng tinggi } \\
\text { tuntas }\end{array}$ & $\begin{array}{c}\text { Jumlah } \\
\text { paling } \\
\text { rendah } \\
\text { tuntas }\end{array}$ & $\begin{array}{c}\text { Jumlahpali } \\
\text { ng tinggi } \\
\text { tuntas }\end{array}$ & $\begin{array}{c}\text { Jumlah } \\
\text { paling } \\
\text { rendah } \\
\text { tuntas }\end{array}$ \\
\hline 1. & Siklus 1 & 192 & 96 & 184 & 125 & 192 & 152 \\
\hline 2. & Siklus 2 & 192 & 127 & 186 & 131 & 192 & 125 \\
\hline
\end{tabular}

Hasil belajar dari rumah/belajar jarak jauhdi SMP Negeri 3 Singkawang pada siklus 1 dan siklus 2. Pada siklus 1 kelas 7 jumlah paling tinggi tuntas 192 siswa (tuntas semua) dan jumlah paling rendah tuntas 96 siswa, kelas 8 jumlah paling tinggi tuntas 184 siswa dan jumlah paling rendah tuntas 125 siswa, kelas 9 jumlah paling tinggi tuntas 192 siswa (tuntas semua) dan jumlah paling rendah tuntas 152 siswa. Pada siklus 2 kelas 7 jumlah paling tinggi tuntas 192 siswa (tuntas semua) dan jumlah paling rendah tuntas 127 siswa, kelas 8 jumlah paling tinggi tuntas 186 siswa dan jumlah paling rendah tuntas 131 siswa, kelas 9 jumlah paling tinggi tuntas 192 siswa (tuntas semua) dan jumlah paling rendah tuntas 125 siswa.

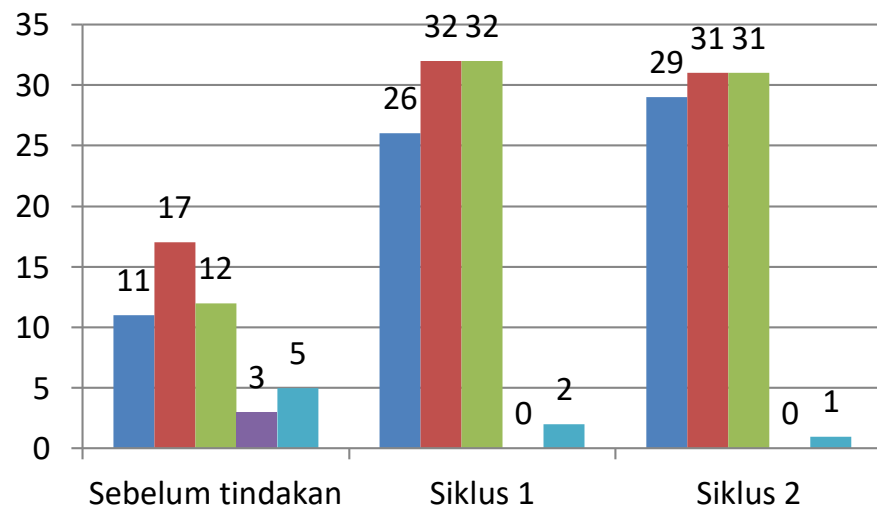

\author{
Video Youtube \\ WAG Kelas \\ GCR (Google Class Room) \\ Quizizz \\ Zoom
}

Grafik 5.Belajar Dari Rumah/Belajar Jarak Jauh di SMP Negeri 3 Singkawang sebelum dan setelah tindakan sekolah

Belajar dari rumah/belajar jarak jauh di SMP Negeri 3 Singkawang sebelum dan setelah tindakan sekolah.Sebelum tindakan media interaksi yang digunakan guru paling banyak menggunakan media interaksi whatsapp grup kelas. Pada siklus 1 dan siklus 2 media interaksi yang digunakan semua guru adalah whatsaap grup kelas dan google class room sesuai dengan yang dibuat olah manajemen sekolah.

Tabel 5. Belajar Dari Rumah/Belajar Jarak Jauh di SMP Negeri 3 Singkawang sebelum dan setelah tindakan sekolah

\begin{tabular}{llccc}
\hline \multirow{2}{*}{ No } & Media interkasi yang digunakan & \multirow{2}{*}{$\begin{array}{c}\text { Sebelum } \\
\text { guru }\end{array}$} & & \multicolumn{2}{c}{ Setelah tindakan } \\
\cline { 4 - 5 } & & $34,37 \%$ & $81,25 \%$ & $93,54 \%$ \\
\hline 1. & Video youtube & $53,12 \%$ & $100 \%$ & $100 \%$ \\
\hline 2. & WhatsApp Grup Kelas (WAG) & $37,50 \%$ & $100 \%$ & $100 \%$ \\
\hline 3. & Google Class Room (GCR) & $9,37 \%$ & $0 \%$ & $0 \%$ \\
\hline 4. & Quizizz & $15,62 \%$ & $6,25 \%$ & $3,23 \%$ \\
\hline 5. & Zoom &
\end{tabular}

Media interaksi yang digunakan untuk belajar dari rumah/belajar jarak jauh di SMP Negeri 3 Singkawang yaitu video youtube, whatsapp grup kelas (WAG).google class room (GCR), quizizz, dan zoom. Media video youtube digunakan guru sebelum tindakan 34,37\%, pada siklus 1 meningkat menjadi $81,25 \%$, dan 
pada siklus 2 meningkat menjadi 93,54\%. Media interaksi whatsapp grup kelas digunakan guru sebelum tindakan 53,12\%, pada siklus 1 meningkat menjadi $100 \%$, dan pada siklus 2 bertahan $100 \%$. Media interaksi google class room digunakan guru sebelum tindakan 38,71\%, pada siklus 1 meningkat menjadi $100 \%$, dan pada siklus 2 bertahan $100 \%$. Media interaksi quizizz digunakan guru sebelum tindakan $9,37 \%$, pada siklus 1 tidak ada uang menggunakan jadi $0 \%$, dan pada siklus 2 juga tidak ada guru yang menggunakan jadi $0 \%$. Media interaksi zoom digunakan guru sebelum tindakan 16,12\%, pada siklus 1 turun menjadi 6,25\%, dan pada siklus 2 turun menjadi 3,23\%.

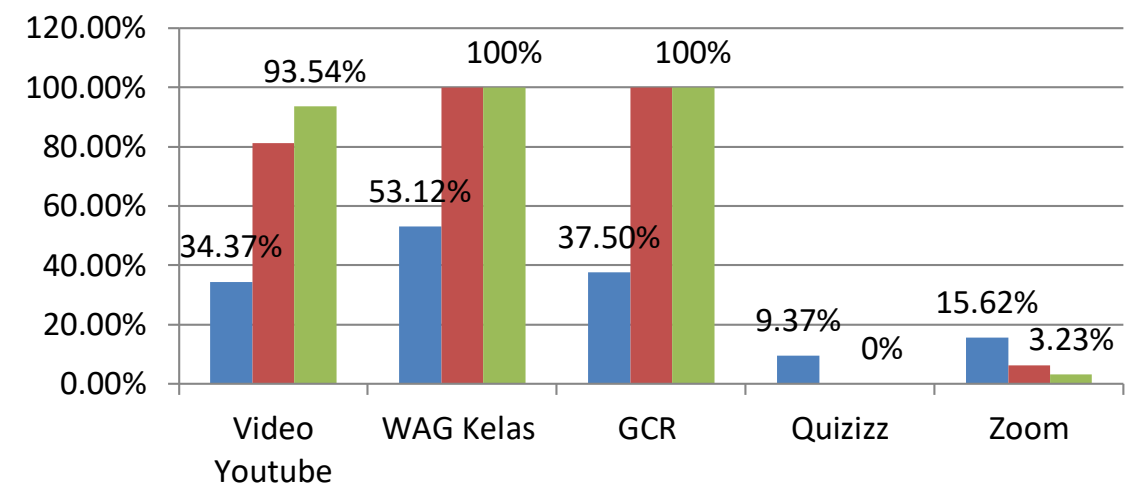

Grafik 6.

Persentasi media interaksi yang digunakan Guru Belajar Dari Rumah/Belajar Jarak Jauh di SMP Negeri 3 Singkawang sebelum dan setelah tindakan sekolah

Media interaksi video youtube meningkat signifikan dari sebelum tindakan sampai siklus 1 dan siklus 2 karena guru SMP Negeri 3 Singkawang dianjurkan untuk membuat video pembelajaran yang diunggah di youtube SMP Negeri 3 Singkawang. Guru dibebaskan untuk menggunakan media interaksi dalam belajar dari rumah/belajar jarak jauh namun yang wajib digunakan yaitu whatsapp grup kelas dan google class room karena merupakan media yang dibuat manajemen sekolah untuk mengontrol proses pembelajaran belajar dari rumah/belajar jarak jauh di SMP Negeri 3 Singkawang. Maka media interaksi whatsapp grup kelas dan google class room 100\% digunakan pada siklus 1 dan siklus 2.

\section{KESIMPULANDANSARAN}

Dapat disimpulkan bahwa untuk meningkatkan pembelajaran pada masa pandemi Covid-19 dengan belajar dari rumah/belajar jarak jauh dengan menggunkan media interaksi yang disiapkan oleh manajemen sekolah. Manajemen SMP Negeri 3 Singkawang memanfaatkan media interaksi yang murah dan mudah digunakan oleh guru dan siswa.

Pada masa pandemi Covid-19 ini menjadikan semua guru SMP Negeri 3 Singkawang terampil menggunakan media TIK dan mampu membuat video pembelajaran yang diunggah di youtube SMP Negeri 3 Singkawang.Pelayanan belajar dari rumah/belajar jarak jauh kepada siswa berjalan lancar.

Kegiatan belajar dari rumah/belajar jarak jauh dengan memanfaatkan media interaksi yang terkontrol oleh manajemen sekolah dapat meningkatkan pembelajaran pada masa pandemi Covid-19.Sebaiknya sekolah lain juga dapat menerapkan kegiatan belajar dari rumah/belajar jarak jauh dengan memanfaatkan media interaksi yang terkontrol oleh manajemen sekolah. 


\section{DAFTAR PUSTAKA}

Anggraeni, P., \& Akbar, A. 2018. Kesesuaian rencana pelaksanaan pembelajaran dan proses pembelajaran. Jurnal Pesona Dasar, 6(2).

Aunurrahman. 2009. Belajar dan Pembelajaran.Bandung: Alfabeta.

Darmadi, H. 2016. Tugas, peran, kompetensi, dan tanggung jawab menjadi guru profesional. Edukasi: Jurnal Pendidikan, 13(2), 161-174.

Hamid, A. 2017. Guru Profesional. Al-Falah: Jurnal Ilmiah Keislaman dan Kemasyarakatan, 17(2), 274-285.

Jihad, Asep. 2010. Evaluasi Pembelajaran. Yogyakarta: Multi Pressindo.

Muhamad Surya. (2004). Psikologi Pembelajaran dan Pengajaran. Bandung: Pustaka Bani Quraisyi.

Pane, A., \& Dasopang, M. D. 2017. Belajar dan pembelajaran. Fitrah: Jurnal Kajian Ilmu-Ilmu Keislaman, 3(2), 333-352.

Permendikbud No. 22 tahun 2016. Tentang Standar Proses Pendidikan Dasar dan Menengah.

Surat Edaran Nomor 15 Tahun 2020. Tentang Pedoman Penyelenggaraan Belajar Dari Rumah Dalam Masa Darurat Penyebaran Corona Virus Disease (Covid-19).

Susanto. 2020. Kunci Pembelajaran Jarak Jauh. Kompas.com (dikunjungi Selasa, 14 April 2020). 